\title{
Fenomena Ibu Tunggal dan Masa Depan Warga Tua Desa di Malaysia
}

\author{
WAN IBRAHIM WAN AHMAD
}

\begin{abstract}
This article examines how changes in family institutions especially the increasing of single parents, affect the future of the elderly in society. To date single parents amongst the Malay society in Malaysia can be considered as a social phenomena, whereas at the same time, the magnitude and the proportion of the elderly are increasing. Based on 500 samples amongst single parents in Kelantan, Terengganu and Pahang, this article shows that these single parents, dispite their main task to take care of their elderly members, they themselves are full of daily problems. This situation can influence the future of the elderly in society. Thus, this article suggests strong support for the creation of caring society in Malaysia.
\end{abstract}

\begin{abstract}
ABSTRAK
Artikel ini bertujuan untuk menganalisis perubahan dalam institusi keluarga, khususnya kewujudan ibu tunggal yang mempunyai implikasi ke atas masa depan warga tua dalam masyarakat. Dewasa ini, fenomena ibu tunggal di kalangan masyarakat Melayu di Malaysia tidak lagi dianggap sebagai bersifat individu, tetapi telah menjadi fenomena sosial yang memerlukan kerjasama pelbagai pihak untuk membendungnya. Tambahan lagi dalam masa yang sama jumlah warga tua semakin meningkat. Berasaskan sampel 500 orang ibu tunggal di Kelantan, Terengganu dan Pahang, artikel ini mendapati sebahagian besar ibu tunggal ini tergolong ke dalam kategori sosioekonomi yang rendah dan menghadapi pelbagai masalah harian. Sesuai dengan status wanita sebagai penjaga utama warga tua, ibu tunggal yang bermasalah dalam masyarakat dijangka meninggalkan cabaran ke atas warga tua. Untuk mempastikan tradisi wanita sebagai penjaga utama warga tua tidak terhakis, artikel ini berpendapat masyarakat yang menyayangi warga tua perlu dipupuk.
\end{abstract}

\section{PENGENALAN}

Akhir-akhir ini di serata dunia bentuk dan fungsi keluarga dan kehidupan berkeluarga telah banyak berubah. Salah satu bentuk perubahan tersebut 
bahagian, iaitu 1) modenisasi, kestabilan perkahwinan dan ibu tunggal di Malaysia, 2) ibu tunggal Melayu desa di Pantai Timur, 3) cabaran kepada masa depan warga tua, serta 4) harapan masa depan.

\section{MODENISASI, KESTABILAN PERKAHWINAN DAN IBU TUNGGAL DI MALAYSIA}

Di Malaysia, seperti juga di tempat lain di dunia, masalah ibu tunggal adalah lebih ketara di bandar akibat proses modenisasi, industrialisasi dan urbanisasi yang lebih pesat di kawasan bandar. Proses modenisasi, industrialisasi dan urbanisasi ini boleh mempengaruhi pelbagai pembolehubah keluarga (family variables) yang akhirnya berpengaruh pula ke atas sikap dan nilai seseorang terhadap kestabilan perkahwinan. Akibat perubahan sosioekonomi yang pesat juga keluarga telah kehilangan banyak fungsi dan semakin banyak rumah tangga yang dibina berakhir dengan perceraian. Ahli struktural fungsional (structural functional) seperti Parson, Bales atau Smelser, percaya pemindahan sebahagian fungsi keluarga kepada institusi lain seperti kilang dan industri telah melemahkan institusi keluarga dan berubahnya bentuk keluarga daripada ekstended (extended) kepada nuklear (nuclear) (Ruggles \& Goeken, 1992:16). Dengan itu, ibu tunggal dijangka mempunyai masalah yang semakin rumit yang memerlukan sokongan pelbagai pihak. Berdasarkan kepada perspektif structural functional, jika masyarakat mahukan ibu tunggal berada dalam kehidupan yang harmoni, maka semua pihak atau bahagian dalam masyarakat perlu saling bantu membantu, memberikan sokongan dan kerjasama agar kategori penduduk ini mempunyai keyakinan dan kemampuan untuk memecah dan mengatasi permasalahan harian mereka.

Modenisasi ialah perubahan masyarakat. Masyarakat, tempat di mana institusi keluarga itu berada, sentiasa berada dalam perubahan. Tidak ada satu masyarakatpun di dunia ini, biar bagaimana mundurpun masyarakat itu yang boleh dikatakan berada dalam keadaan statik. Cuma apa yang berbeza ialah dari segi darjah perubahannya sahaja, iaitu ada masyarakat yang berubah dengan amat cepat, dan ada pula masyarakat yang amat perlahan berubah. Oleh itu, dapat dikatakan bahawa modenisasi yang terjadi ke atas masyarakat adalah bersifat sejagat. Modenisasi ialah satu proses perubahan secara menyeluruh yang terjadi ke atas semua aspek kehidupan dalam sesuatu masyarakat yang akhirnya menukar wajah suatu masyarakat itu daripada berunsurkan ciri tradisional kepada suatu keadaan yang bercirikan moden atau tidak tradisional. Bagi masyarakat Barat, yang dikatakan moden atau maju itu sebenarnya adalah tidak lebih daripada penyerapan unsur atau ciri Barat dalam kehidupan bermasyarakat, seperti kata Wilbert Moore (1963):

Modernization is a total transformation of a traditional or pre-modern society into the types of technology and associated 
ialah keluarga dan kehidupan berkeluarga orang tua tunggal. Dalam makalah ini tumpuan adalah ditujukan kepada kehidupan ibu tunggal. Peningkatan bilangan ibu tunggal di kalangan masyarakat Melayu di Malaysia dewasa ini sangat ketara. Terengganu adalah sebuah negeri di Pantai Timur yang termasuk dalam kategori negeri yang mempunyai kadar perceraian yang agak tinggi di Malaysia. Dua negeri lain di Pantai Timur, iaitu Kelantan dan Pahang, walaupun mempunyai kadar perceraian yang lebih rendah, tetapi sering dirujuk sebagai negeri yang mempunyai banyak masalah berkaitan perceraian ini. Sebagai akibatnya dijangkakan Pantai Timur mempunyai ramai ibu yang tergolong dalam kategori ibu tunggal yang bermasalah. Antara sebab yang menjadikan wanita ibu tunggal ialah perceraian, kematian suami, ditinggalkan suami, isteri yang suaminya sakit terlantar, wanita ibu ganti atau ibu tanpa nikah.

Perceraian adalah salah satu faktor yang menyumbang kepada peningkatan ibu tunggal. Antara punca perceraian ialah umur pada perkahwinan pertama yang semakin meningkat, kestabilan perkahwinan yang semakin rapuh, serta penglibatan wanita dalam tenaga kerja di luar rumah. Dengan meningkatnya perceraian, di samping pelbagai sebab yang lain menjadikan jumlah ibu tunggal dalam masyarakat bertambah. Menurut Rohaty Mohd. Majzub dan Muhammad Rais Abdul Karim (1999) ibu tunggal ialah wanita yang; 1) suaminya telah meninggal, dan wanita tersebut terpaksa meneruskan tugas membesarkan anak-anak sendiri; 2) telah bercerai dengan suami, dan telah diberikan hak penjagaan ke atas anak-anak, 3) isteri yang digantung tidak bertali dan tidak diberikan nafkah oleh suami untuk menyara hidup anak-anak, atau 4) wanita yang berada dalam proses perceraian yang mungkin mengambil masa yang lama, dan anak-anaknya masih berada di bawah jagaannya. Selain itu dua penulis ini juga mengkategori ibu tunggal sebagai wanita yang suaminya tinggal berasingan dan suaminya tidak memainkan peranan sebagai bapa dalam keluarga, wanita yang suaminya uzur yang tidak mampu membesarkan anak-anak, atau wanita yang diberikan tugas membesarkan anak orang lain tanpa pertolongan suami. Ibu tunggal yang kekal meneruskan kehidupan berkeluarga dengan anak-anak mereka menghasilkan satu bentuk keluarga yang disebut keluarga orang tua tunggal. Peningkatan keluarga orang tua tunggal dikenalpasti sebagai salah satu bentuk perubahan yang berlaku dalam institusi keluarga dan kehidupan berkeluarga. Perubahan lain termasuklah perubahan dari segi bentuk keluarga (daripada ekstended kepada nuklear), perubahan dari segi saiz, perubahan dari segi peranan dan pembuat keputusan keluarga, atau perubahan dari segi kuasa ibu bapa.

Perubahan ke atas institusi keluarga boleh meninggalkan cabaran ke atas masa depan warga tua. Sehubungan itu artikel ini bertujuan menganalisis salah satu perubahan ini, iaitu pertambahan wanita yang berstatus ibu tunggal serta cuba menonjolkan implikasinya ke atas masa depan warga tua desa di Malaysia. Untuk menuju kepada perbincangan ini, artikel ini dibahagikan kepada empat 
berleluasa. Oleh itu persoalan berkaitan perkahwinan dan perceraian telah berjaya menarik minat para pengkaji, terutama para sarjana antropologi dan sosiologi. Para sarjana kedua-dua bidang ini pada umumnya menumpukan kajian mereka kepada analisis mengenai perkaitan di antara pelbagai faktor sosial, budaya, ekonomi, sistem kepercayaan dan agama dengan pola perkahwinan dan perceraian. Apapun hasil kajian yang telah diketengahkan, namun perceraian terus berlaku, dan akibatnya semakin banyak keluarga yang diketuai oleh ibu atau bapa tunggal wujud dalam masyarakat. Oleh itu akibat proses pemodenan, kestabilan perkahwinan menjadi semakin rapuh. Ahli sosiologi keluarga, seperti Yaacob Harun (1992) umpamanya berpendapat ketidakstabilan perkahwinan adalah disebabkan berlakunya perubahan fungsi keluarga. Banyak fungsi yang sepatutnya dipikul keluarga tradisional, seperti fungsi ekonomi, pendidikan, keagamaan, perlindungan, dan lain-lain, telah diambilalih oleh institusi lain. Akibatnya kekuatan keluarga menjadi semakin lemah. Keluarga yang semakin kehilangan fungsi akan menjadi semakin lemah. Konflik rumah tangga boleh berlaku jika ahli keluarga gagal atau tidak dapat memainkan fungsi masingmasing. Keadaan ini didapati selaras dengan hasil penemuan Jack Dominian (1981) melalui bukunya Marriage, Faith and Love yang mengatakan terdapat hubungan yang rapat di antara kadar perceraian dengan pemodenan. Apapun konflik rumah tangga dan perceraian boleh membawa kepada kewujudan ibu atau bapa tunggal.

\section{IBU TUNGGAL MELAYU DESA DI PANTAI TIMUR: BEBERAPA CIRI LATAR BELAKANG}

Ibu tunggal adalah salah satu sumber sokongan kepada warga tua. Akan tetapi kebanyakan ibu tunggal itu sendiri berhadapan dengan pelbagaimasalah yang menjadikan sukar bagi mereka berfungsi sebagai sumber penjagaan kepada warga tua. Untuk menganalisis fenomena ibu tunggal secara lebih dekat, satu kajian telah dilakukan ke atas 500 orang ibu tunggal di negeri Kelantan, Terengganu dan Pahang (Wan Ibrahim Wan Ahmad, 2003). Untuk mengenali lebih dekat siapa ibu tunggal ini, di bawah ini diturunkan aspek latar belakang sosiodemografi dan ekonomi mereka (Jadual 1).

\section{Umur}

Daripada 500 ibu tunggal yang menjadi responden, sejumlah 481 orang memberikan maklumbalas mengenai umur. Umur ibu tunggal yang paling muda ialah 26 tahun, sementara yang paling tua 70 tahun. Min umur ibu tunggal yang diperolehi ialah 44.5 tahun, dengan umur mod dan umur penengah ialah 45 tahun. Melalui umur mod, dikatakan ibu tunggal yang paling kerap ditemui dalam kajian ialah berumur 45 tahun. Ibu tunggal berumur antara 45-54 tahun 


\section{social organization that characterize the advanced, economically prosperous, and relatively politically stable nations of the Western World.}

Masyarakat ialah satu pengelompokan penduduk yang saling berinteraksi berasaskan peranan masing-masing. Masyarakat adalah konsep yang abstrak yang dibangunkan oleh beberapa tiang seri, yang dipanggil institusi masyarakat. Institusi ini termasuk institusi pendidikan, agama, ekonomi, politik, dan keluarga. Akibat proses modenisasi, institusi ini mengalami perubahan. Salah satu institusi yang berubah ialah institusi keluarga. Secara umum, keluarga ialah sekelompok manusia yang mempunyai hubungan perkahwinan, hubungan darah atau angkat, tinggal serumah, berinteraksi serta berhubung antara satu sama lain berasaskan peranan sosial masing-masing sebagai suami dan isteri, ibu dan bapa, anak lelaki dan anak perempuan, abang, kakak dan adik, dan mewujudkan serta mengekalkan budaya yang sama (Burges et al. 1971).

Modenisasi boleh diertikan sebagai pembangunan sosioekonomi. Dewasa ini dapat dikatakan semua negara sedang membangunkan aspek sosioekonomi mereka. Akibatnya pelbagai kesan positif telah dapat dirasai oleh kebanyakan penduduk di negara berkaitan. Malaysia juga sedang membangun dengan pesat. Sejak Dasar Ekonomi Baru dilancarkan (1971), Malaysia berjaya mengorak langkah ke arah kemajuan, dan dijangka mencapai status negara maju pada 2020. Terdapat pelbagai petunjuk yang menunjukkan berlakunya pembangunan yang pesat di Malaysia. Antaranya ialah peningkatan taraf hidup penduduk, kadar celik huruf, kadar kematian bayi, bilangan doktor per 1000 penduduk, dan pendapatan per kapita. Petunjuk ini merupakan kesan positif akibat pembangunan yang pesat. Ia juga melambangkan Malaysia telah membangun dan kini sudah jauh lebih maju daripada sesetengah negara lain yang sedang membangun. Selain kesan positif, terdapat juga kesan negatif akibat pembangunan pesat. Kesan negatif ini datang seiring dengan proses pembangunan yang dilaksanakan. Dengan kata lain, pembangunan juga turut mewujudkan kesan negatif. Salah satu kesan negatif ialah dalam konteks kestabilan perkahwinan. Zainab Ismail (2001) dalam kajiannya ke atas pasangan yang bermasalah di Jabatan Agama Islam Wilayah Persekutuan, menyatakan akibat perubahan sosioekonomi yang pesat, banyak rumah tangga berakhir dengan perceraian. Beliau turut mengatakan masalah perceraian dan konflik rumah tangga kini sudah menjadi masalah negara dan memerlukan sokongan dan kerjasama pelbagai pihak untuk menanganinya.

Perceraian melahirkan keluarga ibu atau bapa tunggal. Di Malaysia, keluarga seperti ini boleh ditemui di mana-mana, sama ada di Terengganu, Kelantan, Pahang, atau di negeri manapun juga di Malaysia. Perceraian dan fenomena ibu bapa tunggal kini bukan lagi boleh dianggap sebagai fenomena bersifat individu, tetapi dianggap sebagai satu fenomena sosial yang semakin 
(sambungan Jadual 1)

$\begin{array}{lrc}\text { Latar Belakang } & \text { Jumlah } & \text { Peratus } \\ \text { Diploma/Sijil } & 4 & 0.8 \\ \text { Universiti } & 7 & 1.4 \\ \text { Bidang Pekerjaan } & 50 & 17.5 \\ \text { Peti- } & 61 & 37.6 \\ \text { Buruh } & 69 & 19.5 \\ \text { Penian Kant } & 5 & 19.7 \\ \text { Usahawan } & 80 & 3.4 \\ \text { Makan Gaji (swasta) } & 52 & 0.8 \\ \text { Makan Gaji (kerajaan) } & & \\ \text { Jumlah Pendapatan } & 338 & 67.6 \\ \text { RM529.00 dan kurang } & 32 & 6.4 \\ \text { RM530 - 929 } & 13 & 2.6 \\ \text { RM939 - 1329 } & 19 & 3.8 \\ \text { RM1330 dan ke atas } & & \\ & 500 & 100.0\end{array}$

\section{Tempoh Perkahwinan Sebelum Menjadi Ibu Tunggal}

Melalui analisis ke atas tempoh perkahwinan dapat diketahui tempoh umur yang manakah yang pada umumnya mempunyai risiko yang tinggi serta mudah berlaku konflik dan seterusnya perceraian yang mewujudkan ibu tunggal dalam masyarakat. Tempoh perkahwinan ibu tunggal yang dikaji adalah berbezabeza, daripada tidak sampai setahun hinggalah kepada 40 tahun. Bagaimanapun untuk kedua-dua tempoh ini, jumlahnya wanita yang layak dijadikan responden adalah tidak besar. Hanya seorang wanita yang telah menjadi ibu tunggal dengan tempoh perkahwinan yang tidak sampai setahun yang mempunyai anak, dan tiga orang telah menjadi ibu tunggal setelah 40 tahun berkahwin. Daripada tempoh ini, didapati min keseluruhan tempoh perkahwinan sebelum menjadi ibu tunggal ialah 17.7 tahun dengan umur mod dan umur mediannya ialah masing-masing 17 tahun.

Melalui angka-angka ini, didapati tempoh perkahwinan bagi sebahagian besar responden ialah 17 tahun, dan separuh daripada mereka menjadi ibu tunggal setelah berumah tangga melebihi 17 tahun dan separuhnya lagi menjadi ibu tunggal setelah berkahwin selama tempoh masa yang kurang daripada 17 tahun. Didapati 60 peratus responden telah menjadi ibu tunggal setelah berumah tangga daripada jangkamasa tidak sampai setahun sehinggalah menjangkau 19 tahun, dan bahkan sebanyak 89.4 peratus menjadi ibu tunggal setelah berumah 
merupakan kategori yang paling ramai. Ibu tunggal dalam kategori umur ini ialah heriumlah 437 peratus Ihw tungoal herwmur antara 35-44 tahun juga tinggi, berjumlah 36.8 peratus ( Jadual 1).

Jadual 1

Beberapa Ciri Latar Belakang Ibu Tunggal

Latar Belakang Jumlah $\quad$ Peratus

Umur

34 dan kurang $\quad 39 \quad 8.1$

$\begin{array}{lll}35-44 & 177 & 36.8\end{array}$

$\begin{array}{lll}45-54 & 210 & 43.7\end{array}$

55 dan lebih $\quad 55 \quad 11.4$

Tempoh Perkahwinan

9 dan kurang $\quad 78 \quad 18.4$

$10-19 \quad 176 \quad 41.6$

30 dan lebih $\quad 45 \quad 10.6$

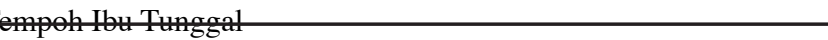

5 dan kurang $\quad 243 \quad 52.1$

$6-10$ tahun $\quad 141 \quad 30.3$

$11-15$ tahun $\quad 64 \quad 13.7$

16 dan ke atas $\quad 18 \quad 3.9$

Sebab Ibu Tunggal

Ditinggalkan suami $\quad 25 \quad 5.1$

Diceraikan suami $\quad 91 \quad 18.5$

$\begin{array}{lll}\text { Kematian suami } & 366 & 74.2\end{array}$

Tidak dinyatakan $\quad 18 \quad 3.6$

Umur Perkahwinan Pertama

19 dan kurang $\quad 221 \quad 49.6$

$20-26 \quad 202 \quad 45.3$

$\begin{array}{lll}27-33 & 19 & 4.3\end{array}$

34 dan lebih $\quad 4 \quad 0.9$

Jumlah Anak

3 dan kurang $\quad 113 \quad 22.7$

$\begin{array}{lll}4-6 & 199 & 40.0\end{array}$

$\begin{array}{lll}7-9 & 134 & 27.0\end{array}$

10 dan lebih $\quad 51 \quad 10.3$

Tahap Pendidikan

Tidak Bersekolah $\quad 87 \quad 17.5$

$\begin{array}{lrr}\text { Sekolah Rendah } & 187 & 37.6\end{array}$

Sijil Rendah Pelajaran $\quad 97 \quad 19.5$

Sijil Pelajaran Malaysia $\quad 98 \quad 19.7$

$\begin{array}{lrr}\text { Sijil Tinggi Persekolahan } & 17 & 3.4\end{array}$ 
tahun. Tempoh penengah ibu tunggal ini menjadi ibu tunggal ialah 6.0 tahun, yang bererti daripada keseluruhan ibu tunggal yang menjadi responden, separuh daripadanya telah menjadi ibu tunggal kurang daripada enam tahun, dan separuh daripada responden lagi telah menjadi ibu tunggal dalam tempoh masa yang melebihi enam tahun. Namun, tempoh yang menjadi mod kepada ibu tunggal ini ialah satu tahun, di mana terdapat 47 responden (10.1\%) yang telah menjadi ibu tunggal dalam tempoh masa selama setahun. Ibu tunggal yang lain didapati telah menjadi ibu tunggal dalam tempoh masa yang berbeza-beza, dan jumlah mereka yang menjadi ibu tunggal dalam tempoh masa ini adalah lebih kecil daripada jumlah mereka yang menjadi ibu tunggal selama setahun. Setelah data mentah ini dikategorikan semula menjadi empat kategori, didapati lebih separuh responden telah menjadi ibu tunggal untuk tempoh masa selama di antara 5 tahun dan kurang (52.1\%), iaitu satu tempoh masa yang boleh dikatakan masih baru. Jumlah lain yang juga agak besar ialah mereka yang menjadi ibu tunggal dalam tempoh masa di antara $6-10$ tahun (30.3\%). Tempoh menjadi ibu tunggal dalam kategori lain tidak besar yang menunjukkan tidak ramai ibu tunggal menjadi ibu tunggal untuk tempoh masa ini.

\section{Sebab Menjadi Ibu Tunggal}

Apakah sebab yang membawa kepada responden menjadi ibu tunggal? Terdapat tiga sebab utama yang telah membawa responden menjadi ibu tunggal di kawasan kajian, iaitu ditinggalkan suami, diceraikan suami, dan kematian suami. Selain daripada sebab ini, terdapat juga sebahagian responden yang tidak menyatakan sebab mereka menjadi ibu tunggal, dan dalam analisis ini sebab ini dinyatakan sebagai sebab yang tidak dinyatakan. Daripada tiga sebab ini, lebih kurang tiga per empat daripada ibu tunggal ini menjadi ibu tunggal disebabkan kematian suami, dan ini melibatkan sejumlah 74.2 peratus ibu tunggal. Sebab lain yang juga agak ramai menimpa responden ialah diceraikan suami, iaitu melibatkan sejumlah 18.5 peratus. Responden yang menjadi ibu tunggal disebabkan ditinggalkan suami adalah tidak ramai, iaitu sejumlah 5.1 peratus sahaja. Oleh itu dapat dikatakan sebahagian besar ibu tunggal menjadi ibu tunggal adalah disebabkan oleh kematian suami. Kematian adalah satu hakikat yang tidak dapat dielakkan. Fenomena ibu tunggal disebabkan kematian suami membawa kepada proses dan tahap adaptasi yang berbeza dengan ibu tunggal disebabkan perceraian. Ibu tunggal kematian suami, selepas beberapa ketika, berkemungkinan menjadi lebih tabah dan dapat menerajui rumah tangga mereka dengan cara yang lebih berjaya berbanding ibu tunggal yang lain. Ini kerana berdasarkan pendapat beberapa orang ibu tunggal yang ditemui, ibu-ibu tunggal ini masih menyayangi suami mereka yang sudah meninggal, dan berusaha sedaya yang mungkin untuk membahagiakan anak-anak selaras dengan kehendak suami mereka yang sudah meninggal. Ibu tunggal ini sebolehbolehnya tidak ingin membiarkan roh suami mereka berkecil hati melihat keadaan rumah tangga mereka yang tidak tenteram. 
tangga dalam lingkungan 29 tahun. Hampir separuh (41.6\%) responden menjadi ibu tunggal setelah berumah tangga antara 10 - 19 tahun. Tempoh lain yang agak besar juga ialah 20 - 29 tahun, melibatkan sejumlah 124 orang (29.3\%). Responden yang telah menjadi ibu tunggal setelah berumah tangga untuk tempoh yang kurang 10 tahun serta melebihi 30 tahun tidak ramai, masing-masing berjumlah 18.4 peratus dan 10.6 peratus.

Daripada analisis ini dapat dikatakan fenomena ibu tunggal boleh berlaku pada semua peringkat umur perkahwinan, sama ada baru berkahwin ataupun mereka yang sudah lama berumah tangga. Ini juga bererti fenomena ibu tunggal boleh terjadi pada semua peringkat umur isteri, sama ada isteri itu masih muda ataupun sudah berumur. Keadaan yang hampir sama juga telah ditunjukkan oleh Zawanah Muhammad (1998) yang mengkaji perkhidmatan kaunseling perkahwinan di Jabatan-jabatan Agama Islam, bahawa walaupun konflik rumah tangga banyak terjadi di kalangan pasangan suami isteri yang berumur di antara 26 - 35 tahun, tetapi konflik boleh juga berlaku kepada pasangan di semua peringkat umur. Konflik membawa kepada perceraian, dan perceraian mewujudkan ibu tunggal. Selain itu seperti yang telah ditunjukkan dalam Jadual 1, sebahagian besar wanita menjadi ibu tunggal dalam kajian ini disebabkan kematian pasangan. Kematian boleh berlaku pada semua peringkat umur perkahwinan, dan kerana itu ibu tunggal boleh wujud pada semua peringkat perkahwinan.

\section{Tempoh Menjadi Ibu Tunggal}

Tempoh menjadi ibu tunggal dalam kajian ini ialah tempoh di mana seseorang responden menjadi ibu tunggal pada masa kajian dilakukan, dikira bermula daripada hari pertama mereka mula hidup dan memikul tanggung jawab sendiri sebagai seorang ibu tunggal, sama ada melalui kematian pasangan, perceraian atau ditinggalkan suami tanpa sebarang nafkah. Di dalam soal selidik, responden diminta untuk memberi maklum balas kepada soalan berkaitan dengan tempoh menjadi ibu tunggal dalam sebutan tahun, iaitu sudah berapa tahun mereka telah menjadi ibu tunggal. Ada kemungkinan responden hanya baru menjadi ibu tunggal. Jumlah yang diberikan ini dibulatkan kepada satu tahun sekiranya jumlah bulan yang dinyatakan itu melebihi enam bulan, dan dikira kosong tahun jika tempoh tersebut kurang daripada enam bulan (Jadual 1).

Berdasarkan penganalisisan terhadap tempoh responden menjadi ibu tunggal, didapati ada di antara mereka yang menjadi ibu tunggal seawal-awalnya satu tahun, dan yang paling lama menjadi ibu tunggal adalah selama 43 tahun. Tempoh yang dilalui oleh ramai responden ialah tempoh di antara $1-10$ tahun. Responden menjadi ibu tunggal dalam tempoh melebihi 10 tahun adalah tidak ramai. Analisis ke atas data mentah tempoh responden menjadi ibu tunggal menunjukkan tempoh purata responden menjadi ibu tunggal ialah selama 7.1 
perkahwinan awal. Jenis perkahwinan ini banyak terjadi di kalangan penduduk Melayu di luar bandar pada era selepas merdeka dan sejurus selepas merdeka.

Pada tahun-tahun 1970-an perkawinan pada umur ini masih banyak dijumpai, baik di luar bandar ataupun di bandar sendiri. Jika diteliti lebih mendalam umur kebanyakan ibu tunggal yang menjadi responden kajian ini, sekitar 265 orang (55.1\%) adalah mereka yang berumur 45 tahun dan ke atas. Oleh yang demikian, kemungkinan besar mereka yang berkahwin pada umur muda ini adalah terdiri daripada kategori responden ini.

\section{Jumlah Anak Yang Dimiliki}

Jumlah anak yang dimiliki seperti yang dimaksudkan dalam kajian ini ialah jumlah anak yang dimiliki ibu tunggal sebelum mereka menjadi ibu tunggal, tanpa mengira sama ada anak tersebut pada masa kajian dilakukan berada dalam jagaannya ataupun tidak. Ibu tunggal ini mungkin sudah beberapa kali menjadi ibu tunggal, dan setiap kali mereka menjadi ibu tunggal, mereka berkemungkinan menambahkan jumlah anak berbanding perkahwinan sebelumnya. Kekerapan menjadi ibu tunggal tidak menjadi persoalan, tetapi yang diambilkira ialah jumlah anak yang mereka miliki sebelum menjadi ibu tunggal semasa kajian dilakukan. Jumlah anak yang dimiliki oleh ibu tunggal yang menjadi responden kajian boleh dikatakan tidak begitu ramai, terutama jika ditinjau dalam konteks masyarakat desa. Berdasarkan data banci Jabatan Perangkaan dan kajian Penduduk dan Keluarga Malaysia oleh Lembaga Penduduk dan Pembangunan Keluarga Negara (LPPKN, t.th.) didapati purata saiz isirumah bagi penduduk luar bandar pada tahun 1980 ialah 5.2 orang. Akhirakhir ini purata ini semakin menurun. Walaupun purata saiz isirumah adalah tidak sama dengan purata jumlah anak, tetapi data ini juga sedikit sebanyak boleh menggambarkan bahawa purata anak yang dimiliki oleh keluarga luar bandar adalah agak ramai, sedangkan melalui kajian ini didapati jumlah yang terbanyak daripada ibu tunggal adalah memiliki anak seramai empat orang.

Terdapat sebilangan kecil ibu tunggal yang tidak memiliki anak. Mereka yang memiliki anak seramai satu orang juga tidak ramai. Jumlah teramai ibu tunggal adalah memiliki anak seramai empat orang. Ibu tunggal yang memiliki anak lima orang lebih rendah sedikit daripada ibu tunggal yang memiliki anak empat orang. Jumlah anak yang juga agak ramai dimiliki ialah enam, tujuh dan lapan orang. Walaupun ada yang memiliki anak melebihi 10 orang, dan bahkan mencapai 13 orang, tetapi jumlah ini tidak ramai. Apabila data ini dikategorikan semula, didapati lebih daripada 60 peratus daripada ibu tunggal (62.7\%) adalah memiliki anak seramai enam orang dan kurang. Terdapat 40 peratus daripada ibu tunggal adalah memiliki anak di antara $4-6$ orang. Jumlah yang agak ramai juga ialah mereka yang memiliki anak seramai 7 - 9 orang (27\%). Ibu tunggal yang memiliki anak melebihi 10 orang adalah tidak ramai. 


\section{Umur Pada Perkahwinan Pertama}

Umur pada perkahwinan pertama dalam kajian ini ialah umur seseorang lelaki atau wanita berkahwin pada pertama kali dalam hidupnya. Pada hari ini umur pada perkahwinan pertama bagi penduduk di Malaysia, sama ada lelaki atau wanita didapati telah meningkat (Palmore \& Marzuki, 1969; Asmah Ahmad, 1979; Nor Laily Abu Bakar et al. 1980; Wan Ibrahim Wan Ahmad, 1990). Umur pada perkahwinan pertama sehingga kini telah menjadi aspek yang menarik minat ramai pengkaji kerana perkaitannya dengan pelbagai aspek demografi dan kekeluargaan. Saiz keluarga, kadar fertiliti, kadar pertumbuhan penduduk, dan malah kestabilan rumah tangga dikatakan banyak ditentukan oleh umur pada perkahwinan pertama ini. Umur pada perkahwinan pertama ibu tunggal seawalawalnya telah ditemui pada umur 13 tahun dan selewat-lewatnya ialah 47 tahun, dengan umur pada perkahwinan pertama yang paling kerap dijumpai ialah 18 tahun. Ini bererti sudah ada ibu tunggal yang telah memulakan perkahwinan pada umur 13 tahun. Ibu tunggal ini ialah mereka yang termasuk generasi tahun 1940-an atau sebelumnya, yang sekarang ini mula memasuki umur tua. Min umur pada perkahwinan pertama bagi keseluruhan ibu tunggal ialah 20 tahun, iaitu umur perkahwinan yang masih dianggap rendah. Umur penengah juga dianggap rendah, iaitu 20 tahun, yang bererti separuh daripada 481 ibu tunggal memulakan perkahwinan pada umur sebelum 20 tahun dan separuhnya lagi memulakan perkahwinan pada umur melebihi 20 tahun. Meneliti umur pada perkahwinan pertama di kawasan kajian ini, didapati tidak ramai ibu tunggal yang memulakan perkahwinan pada umur melebihi 30 tahun. Apabila umur pada perkahwinan pertama ini dikategorikan semula, kira-kira separuh responden telah memulakan perkahwinan pada umur 19 tahun dan kurang. Jumlah yang lebih kurang sama juga didapati daripada kumpulan umur 20 - 26 tahun. Ini bererti lebih 90 peratus daripada responden telah memulakan perkahwinan pada umur 26 tahun dan ke bawah. Hanya lebih kurang lima peratus sahaja daripada mereka yang berkahwin pada umur 27 tahun dan ke atas. Keadaan ini menunjukkan ibu tunggal di kawasan kajian, walaupun ramai yang mula berkahwin agak lewat, tetapi ramai juga yang telahpun memulakan perkahwinan pada umur yang dianggap masih muda.

Hasil kajian ini didapati tidak jauh berbeza dengan beberapa hasil kajian lain mengenai aspek yang sama oleh pengkaji lain di Malaysia. Wan Ibrahim Wan Ahmad (1990), umpamanya yang mengkaji umur pada perkahwinan pertama ini di Kuala Balah, Kelantan telah menunjukkan hasil yang serupa. Hasil analisisnya mengenai pola umur perkahwinan wanita Melayu luar bandar pada tahun akhir 1980-an adalah sebanyak 71.7 peratus daripada wanita yang menjadi responden kepada kajiannya telah memulakan perkahwinan pertama pada umur 19 tahun dan kurang. Wan Ibrahim Wan Ahmad dalam kajian tersebut telah mengkategorikan perkahwinan pada umur 19 tahun dan kurang sebagai 


\section{Pendapatan Bulanan}

Ibu tunggal di kawasan kajian adalah terdiri daripada mereka yang berpendapatan rendah. Pendapatan purata ibu tunggal ini ialah RM447.00 sebulan. Walaupun ada di antara ibu tunggal yang berpendapatan mencapai RM5000 sebulan, tetapi pendapatan yang menjadi mod ialah RM300.00 sebulan, dengan pendapatan menengah ialah juga RM300.00. Pendapatan mentah ini setelah dikategorikan semula, kebanyakan mereka mempunyai pendapatan di bawah garis kemiskinan, di mana 67.6 peratus ibu tunggal melaporkan mempunyai pendapatan di antara RM529 dan ke bawah. Disebabkan kos hidup di kawasan luar bandar yang semakin meningkat maka kebanyakan mereka melaporkan pendapatan yang mereka ada tidak mencukupi untuk memenuhi keperluan hidup berkeluarga. Oleh yang demikian ibu tunggal ini menyatakan mereka tidak menyimpan, malah terpaksa menggunakan semua sekali pendapatan ini untuk keperluan harian. Berasaskan pendapatan garis kemiskinan di Semenanjung Malaysia yang berjumlah RM529.00, maka rata-rata ibu tunggal di Pantai Timur adalah terdiri daripada mereka yang dianggap miskin.

\section{IMPLIKASI PENINGKATAN IBU TUNGGAL KEPADA MASA DEPAN WARGA TUA}

Revolusi demografi yang terjadi di negara maju akibat penurunan kelahiran, beserta dengan adanya kemajuan dalam teknologi perubatan telah menjadikan penduduk tua bertambah, termasuk di Malaysia. Walaupun penduduk yang berumur 65 tahun dan lebih di Malaysia pada hari ini masih lagi kecil jika dibandingkan dengan negara Barat (PBB., 1991), tetapi terdapat tanda-tanda penduduk Malaysia sedang menuju ke arah penuaan (Heisil, 1984). Ini berikutan dengan peningkatan jumlah warga tua dalam struktur penduduk dari tahun ke tahun. Pada 1970, penduduk yang berumur 65 tahun dan lebih di Malaysia ialah seramai 316,852 orang, dan jumlah ini meningkat menjadi 788,000 orang pada 1995 (Jadual 2). Dari segi peratus, ia meningkat daripada 3.1 peratus (1970), kepada 3.9 peratus (1995) dan dijangka meningkat kepada 4.2 peratus (2000) dan 7.3 peratus pada 2020 (PBB., 1991). Ini bererti pada 2020 bilangan warga tua di Malaysia melebihi tujuh peratus yang melayakkan negara ini dikategorikan sebagai negara berpenduduk tua mengikut ukuran PBB (PBB., 1988). Wanita adalah penjaga utama kepada warga tua (Stoller, 1983). Dalam masyarakat Barat, peningkatan wanita dalam tenaga kerja dibimbangi boleh menjejaskan aktiviti penjagaan warga tua (Stoller, 1983; Chappell, 1990). Sehubungan wanita sebagai penjaga utama warga tua, maka peningkatan jumlah ibu tunggal boleh meninggalkan cabaran ke atas penjagaan dan masa depan warga tua. Peningkatan ibu tunggal dalam masyarakat Melayu di Pantai Timur disertai dengan peningkatan jumlah ibu tunggal dalam masyarakat boleh 


\section{Tahap Pendidikan}

Selain status dan tempat tinggal, tahap pendidikan ibu tunggal adalah satu lagi aspek sosioekonomi yang turut dianalisis dalam kajian ini. Tahap pendidikan ini menggambarkan pendidikan tertinggi yang dicapai oleh ibu tunggal. Selalunya tahap pendidikan bagi kebanyakan penduduk adalah semakin meningkat selaras dengan semakin meningkatnya tahap pembangunan negara. Di Malaysia, pada zaman sebelum merdeka atau sejurus selepas merdeka, tahap pendidikan penduduk adalah rendah, malah ramai yang tidak bersekolah langsung, tetapi pada hari ini tidak ramai lagi penduduk yang tidak pernah bersekolah. Pendidikan yang hanya setakat tamat tingkatan tiga sekarang ini masih lagi dianggap sebagai satu tahap pendidikan yang masih rendah. Dalam masyarakat di Malaysia pada hari ini, sama ada di bandar atau di luar bandar, sudah ramai penduduk yang mendapat pendidikan universiti. Sebahagian besar ibu tunggal dalam kajian ini adalah tidak bersekolah dan mendapat pendidikan setakat sekolah rendah sahaja (45.1 peratus). Jika dirujuk kembali Jadual 1 yang memaparkan taburan umur ibu tunggal, didapati sebanyak 45.1 peratus daripada mereka berumur di antara 45 tahun dan ke atas. Ini bermakna bahawa ibu tunggal yang hanya mendapat pendidikan rendah dan tidak sekolah ini adalah terdiri daripada mereka yang berumur 45 tahun dan ke atas, iaitu generasi tahun 1950-an dan sebelumnya. Tahap pendidikan bagi generasi ini adalah agak rendah. Ibu tunggal yang berpendidikan setakat Sijil Rendah Pelajaran dan Sijil Pelajaran Malaysia juga tidak ramai, iaitu masing-masing berjumlah 19.5 peratus dan 19.7 peratus. Jumlah ini adalah satu jumlah yang masih dianggap kecil. Oleh yang demikian dapatlah dikatakan bahawa tahap pendidikan ibu tunggal di kawasan kajian adalah agak rendah dan tidak boleh dibanggakan.

\section{Bidang Pekerjaan}

Bidang pekerjaan sedikit sebanyak adalah berkaitan dengan tahap pendidikan seseorang. Orang yang berpendidikan lebih tinggi pada umumnya akan berpeluang memperoleh pekerjaan yang status sosialnya adalah lebih baik, dan seterusnya dengan pekerjaan yang lebih baik akan memberikan peluang kepada orang tersebut mempunyai pendapatan yang lebih terjamin. Analisis ke atas bidang pekerjaan ibu tunggal mendapati kebanyakan ibu tunggal adalah mempunyai pekerjaan yang bertaraf rendah, terutama di bidang berkaitan dengan pertanian dan pekerjaan di sektor tidak formal. Pekerjaan seperti ini dijangka mempunyai pengaruh tertentu ke atas pola pendapatan dan kualiti hidup ibu tunggal di kawasan kajian. Terdapat enam bidang pekerjaan yang dikenal pasti diceburi ibu tunggal di kawasan kajian, iaitu petani, buruh, peniaga kecil, usahawan, makan gaji (swasta) dan makan gaji (kerajaan). Ada juga sebahagian daripada mereka melaporkan tidak bekerja. 
adalah sokongan yang diberikan oleh negara atau pemerintah, ataupun oleh institusi formal (Atchley, 1988). Sokongan ini berfungsi untuk menyediakan perkhidmatan yang bertujuan menambah, melengkap ataupun menggantikan sokongan tidak formal daripada ahli keluarga dan lain-lain (Cantor \& Little, 1985). Daripada pengalaman beberapa negara, dapat dirumuskan sokongan dan penjagaan ke atas warga tua merupakan tanggungjawab banyak pihak - keluarga, komuniti, pemerintah, swasta badan-badan bukan kerajaan dan lain-lain. Memang peranan keluarga adalah penting, tetapi dari segi realitinya keluarga sendiri semakin tidak mampu untuk memikul tanggungjawab menjaga warga tua tanpa sokongan dan kerjasama daripada pelbagai pihak, khususnya pemerintah dan juga swasta.

Kedua-dua sumber sokongan, sama ada formal mahupun tidak formal adalah saling diperlukan untuk memberikan penjagaan yang sempurna kepada warga tua (Wan Ibrahim Wan Ahmad, 2000). Cantor (1979), melalui pendekatan pelengkap berhirarkinya, menyatakan proses mendapatkan sokongan adalah secara berhirarki dengan pasangan dan anak-anak merupakan sumber asas dalam sistem sokongan. Jika warga tua tidak mendapat sokongan daripada sumber ini, maka warga tua akan mencari adik beradik atau saudara mara yang lain. Jika sekiranya sumber-sumber ini tidak ada maka warga tua akan mencari kawankawan, jiran tetangga, ataupun sebagai sumber alternatif terakhir, organisasi formal untuk mendapatkan sokongan. Berdasarkan pendekatan pelengkap berhirarki ini sokongan sosial dipandang sebagai suatu rantaian jaringan yang berurutan. Jika salah satu sumber dalam jaringan ini tidak ada, maka sumber lain berikutnya dalam jaringan itu akan menggantikan tempat tersebut untuk menyediakan sokongan (Horwitz 1993). Pada umumnya warga tua tidak akan terus mencari sokongan formal. Mereka hanya akan mencari sokongan formal jika sokongan tidak formal tidak dapat diperolehi. Oleh yang demikian, selaras dengan sumber sistem sokongan seperti yang tergambar dalam pendekatan pelengkap berhirarki (Cantor, 1979), maka dengan bertambahnya ibu tunggal dalam masyarakat dijangka boleh mempengaruhi sistem sokongan ke atas warga tua. Ini adalah bersesuaian dengan wanita sebagai penjaga utama dalam sistem sokongan tidak formal. Sistem sokongan formal berkemungkinan terpaksa turut memainkan peranan yang lebih banyak untuk menggantikan peranan keluarga yang menjadi semakin kurang berupaya disebabkan sumber penjagaan keluarga itu sendiri mengalami banyak masalah.

\section{Cabaran Ke Atas Sumber Penjagaan}

Warga tua umumnya adalah golongan yang lemah. Keadaan ini disebabkan keupayaan fizikal mereka yang semakin berkurang (Chua, 1988). Oleh yang demikian warga tua selalunya memerlukan sokongan dan penjagaan (Wan Ibrahim, 1999). Marshall, Rosenthall dan Daciuk (1987) dalam kajian mereka di Amerika Syarikat menunjukkan warga tua yang berumur 80 dan lebih terpaksa 
meninggalkan implikasi tertentu ke atas penjagaan dan masa depan warga tua di situ. Implikasi ini tersebut termasuklah implikasi ke atas sokongan, penjagaan, jaminan kewangan, serta implikasi ke atas jaminan kesejahteraan warga tua.

Jadual 2

Taburan dan Peratusan Penduduk Berumur 65 Tahun dan Lebih di Malaysia (1970 - 2020)

\begin{tabular}{|c|c|c|c|c|}
\hline \multirow{3}{*}{ Tahun } & \multicolumn{2}{|c|}{ Penduduk 60 Th. dan Lebih } & \multicolumn{2}{|c|}{ Penduduk 65 Th dan Leb } \\
\hline & & & & \\
\hline & Jumlah & Peratus & Jumlah & Peratus \\
\hline 1970 & 539118 & 5.2 & 316852 & 3.1 \\
\hline 1975 & 554818 & 5.5 & 356631 & 3.5 \\
\hline 1980 & 745152 & 5.7 & 475407 & 3.6 \\
\hline 1985 & 706902 & 5.2 & 464272 & 3.4 \\
\hline 1991 & 1032310 & 5.9 & 657401 & 3.7 \\
\hline 1995 & 1194000 & 6.0 & 788000 & 3.9 \\
\hline 2000 & 1450000 & 6.6 & 919000 & 4.2 \\
\hline 2005 & 1705000 & 7.2 & 1133000 & 4.8 \\
\hline 2010 & 2094000 & 8.3 & 1340000 & 5.3 \\
\hline 2015 & 2596000 & 9.7 & 1665000 & 6.2 \\
\hline 2020 & 3216000 & 11.3 & 2079000 & 7.3 \\
\hline
\end{tabular}

Sumber:

Jabatan Perangkaan Malaysia (1973; 1974; 1983; 1985).

PBB (1991) - Unjuran Penduduk Dunia 1995-2020.

\section{Implikasi ke Atas Sistem Sokongan}

Semua negara mempunyai sistem sokongan yang tersendiri untuk penduduk tuanya. Sistem sokongan ini diwujudkan bertujuan untuk menjaga warga tua supaya sentiasa hidup sejahtera. Di negara maju sistem sokongan ini pada umumnya menjadi tanggung jawab pemerintah, manakala di negara membangun sistem sokongan lebih merupakan tanggung jawab keluarga. Konsep sokongan sosial, yang sering disebut sebagai sistem sokongan dalam kepustakaan mengenai warga tua, merujuk kepada wujud atau tidak jaringan ataupun apa sahaja tindakan, sikap serta iklim yang bersifat menyokong yang disediakan oleh orang lain kepada warga tua (Wan Ibrahim Wan Ahmad, 2000). Sistem sokongan ini pada umumnya dikategorikan kepada dua, iaitu sokongan tidak formal dan sokongan formal. Sokongan tidak formal ialah sokongan yang tidak mempunyai struktur yang khusus, tidak terikat dengan birokrasi, tidak tersusun, tidak berdaftar, serta diberikan berasaskan kepada hubungan dan peranan sosial. Termasuk dalam sokongan jenis ini ialah sokongan yang diberikan oleh ahli keluarga, kawan-kawan serta jiran tetangga. Sokongan formal pula 
sokongan kewangan dan penjagaan utama warga tua, iaitu 72.6 peratus warga tua lelaki dan 89.9 peratus warga tua perempuan bergantung kepada anak sebagai sumber kewangan.

Perubahan yang telah dan sedang berlaku ke atas kawasan desa di Malaysia juga boleh menggugat jaminan kewangan yang dapat diberikan anak-anak dan ahli keluarga kepada warga tua. Dengan peningkatan kos hidup dan kos penjagaan anak, terutama yang dialami anak perempuan berstatus ibu tunggal, jaminan kewangan yang dapat disumbangkan kepada warga tua oleh anak perempuan ibu tunggal ini boleh terjejas, lebih-lebih lagi jika ibu tunggal ini adalah berpendapatan rendah. Pengecilan saiz keluarga di Malaysia sekarang ini juga memberikan pengaruh yang kuat ke atas jaminan kewangan warga tua, kerana bilangan anak yang berpotensi sebagai sumber kewangan kepada warga tua berkurangan. Keadaan ini menyebabkan warga tua yang tidak mempunyai anak terpaksa terus berkerja walaupun mencapai umur lanjut. Mereka akan terus bekerja selagi terdaya untuk menyara kehidupan. Daripada pemerhatian sama ada secara formal mahupun tidak formal, yang telah dilakukan ke atas kehidupan warga tua di Malaysia sejak tahun 1990-an sehingga kini, didapati warga tua yang tidak mempunyai jaminan kewangan berhadapan dengan masalah yang gawat, terutama masalah berkaitan dengan kos perubatan mereka. Umur tua selalunya disertai dengan penurunan taraf kesihatan fizikal. Taraf kesihatan yang rendah menjadikan warga tua lebih bergantung kepada orang lain dan terpaksa mendapat jaminan kewangan daripada ahli keluarga. Semakin kurangnya keupayaan fizikal untuk bergerak, semakin rendah keupayaan warga tua untuk berdikari, yang akhirnya boleh menjadikan mereka semakin memerlukan sokongan dan penjagaan (Stoller 1985; Worobey dan Angel 1990).

Salah satu masalah besar warga tua yang memerlukan kewangan yang besar ialah penyakit buah pinggang. Pengalaman saya bergaul, berinteraksi dan berhadapan dengan warga tua yang mengidap penyakit ini di pelbagai peringkat status sosial, saya dapati warga tua desa yang tidak mempunyai jaminan kewangan menghadapi masalah paling teruk. Pengidap penyakit ini berhadapan dengan masalah buah pinggang yang tidak lagi berfungsi untuk memproses peredaran darah agar darah dalam tubuh mereka tetap bersih dan beroksigen. Tidak ada kaedah lain dalam perubatan moden untuk menyelamat dan memperpanjangkan umur pesakit ini, kecuali dengan melakukan rawatan homeodialisis, iaitu satu kaedah yang menggunakan mesin dialisis yang dapat mengambilalih fungsi buah pinggang untuk meneruskan proses edaran darah yang tidak dapat dilakukan. Saya turut melakukan pemerhatian ke atas pesakit ini di pelbagai hospital di pelbagai negeri. Pesakit terpaksa menjalani rawatan beberapa kali seminggu, malah ada yang mencapai sebanyak tiga kali seminggu. 
mendapat penjagaan yang lebih berbanding warga tua dalam kategori umur yang lebih muda. Dalam masyarakat di manapun juga secara tradisi, kaum wanita memainkan peranan utama dari segi penjagaan terhadap warga tua. Golongan wanita adalah mendominasi tugas penjagaan kepada warga tua.

Dalam masyarakat Malaysia, secara tradisional, wanita juga memainkan peranan utama dari segi penjagaan terhadap warga tua. Bagaimanapun disebabkan perubahan yang telah berlaku ke atas institusi keluarga menjadikan sekarang ini warga tua tidak lagi dapat banyak bergantung kepada anak wanita mereka. Dengan semakin meningkatnya wanita yang mendapat status ibu tunggal boleh meninggalkan kesan tertentu pula ke atas sistem sokongan kepada warga tua ini. Selain itu proses perindustrian dan modenisasi telah membuka peluang pekerjaan kepada wanita dalam sektor formal dan kadar penyertaan mereka dalam pasaran tenaga buruh semakin meningkat. Pada 1980, umpamanya, kadar penyertaan wanita ialah 44.0 peratus dan meningkat kepada 46.9 peratus pada 1992 (Jabatan Perangkaan Malaysia, 1995). Ini bererti hampir separuh kaum wanita dalam lingkungan umur 15-64 tahun telah memasuki barisan tenaga kerja formal. Penyertaan wanita dalam barisan tenaga kerja boleh menjejaskan aktiviti penjagaan warga tua. Anak perempuan yang berkerja dan mempunyai tanggungjawab berkeluarga terpaksa menumpukan perhatiannya kepada pekerjaan dan keluarganya sendiri di samping perlu memberikan perhatian kepada ibu bapa yang sudah tua. Keadaan ini telah dan sedang berlaku di negara kita. Walaupun masalah ini masih belum tenat, tetapi ada tanda-tanda masalah penjagaan warga tua akan menjadi rumit. Kesan awal ialah ramai warga tua tidak lagi boleh bergantung harap kepada anak dan ahli keluarga. Daripada maklumat yang diperolehi daripada Jabatan Kebajikan Masyarakat Wilayah Persekutuan, bilangan warga tua yang mendiami Rumah Sri Kenangan juga sedang bertambah. Dahulu para penghuni di rumah ini kebanyakannya adalah warga tua tanpa waris, melarat, kurang upaya dan hidup di tepi-tepi jalan, tetapi kini, ramai warga tua yang tinggal di situ adalah warga tua yang masih mempunyai anak yang ramai dan ahli keluarga yang berada. Pada penghujung 2005 terdapat kira-kira 1,827 orang warga tua ditempatkan di sembilan buah Rumah Sri Kenangan di seluruh negara (Jabatan Perangkaan Malaysia, 2006).

\section{Cabaran Ke Atas Jaminan Kewangan}

Disebabkan kadar penyertaan warga tua dalam tenaga kerja semakin menurun maka sumber ekonomi mereka berkurang. Beberapa kajian di Malaysia menunjukkan warga tua banyak bergantung kepada keluarga untuk sokongan kewangan dan penjagaan. Strange (1980) dalam kajian di tiga buah kampung di Terengganu mendapati warga tua melahirkan rasa bimbang tentang nasib masa depan masing-masing, kecuali bagi warga tua yang mempunyai anak-anak yang senang. Masitah dan Nazileh (1986) dalam kajian mereka di Negeri Sembilan, Melaka dan Selangor, juga mendapati anak dan ahli keluarga merupakan sumber 


\section{YANG MENYAYANGI WARGA TUA}

Apa yang boleh diharapkan pada masa depan ialah masyarakat yang terus menyayangi warga tua. Masyarakat perlu mewujudkan masyarakat yang menyayangi warga tua. Persekitaran masyarakat yang menyayangi warga tua boleh bermula daripada kita. Kita perlu menyayangi warga tua mulai hari ini. Kalau kita tidak memulakannya, esok, apabila kita tua nanti anggota masyarakat tidak akan menyayangi kita juga. Semasa kita muda, kita mungkin mempunyai kedudukan yang tinggi, mempunyai duit yang banyak atau kita mungkin dihormati oleh masyarakat. Apakah keadaan ini dapat dijamin berterusan apabila kita mencapai umur tua? Pada masa itu kita sudah tidak lagi mempunyai apa-apa kuasa atau prestij yang boleh menarik orang lain menyayangi kita. Tidak ada lagi kuasa yang boleh digunakan untuk menaikkan pangkat orang bawahan kita. Tidak ada lagi prestij yang boleh meninggalkan pengaruh kepada orang-orang tertentu. Jika kita orang yang tidak pernah bekerja dengan kerajaan, kita mungkin menjadi lebih malang lagi kerana pada masa itu kita sudah tidak dapat bekerja dan tidak mempunyai sumber kewangan sendiri untuk meneruskan kehidupan. Sedangkan rasa disayangi, dihormati, dikunjungi dan ada mempunyai duit sendiri adalah penting bagi kesejahteraan seseorang di hari tua mereka.

Daripada pemerhatian yang dibuat, warga tua yang tidak sejahtera dan terpinggir adalah warga tua yang mempunyai tiga ciri besar, iaitu 1) warga tua yang jahil dan tidak mematuhi suruhan-suruhan Tuhannya, 2) warga tua yang tidak mempunyai sumber (pendapatan, harta, dan pelbagai kebolehan lain), serta 3) warga tua yang mempunyai pengalaman yang tidak memberangsangkan dengan ibu bapa mereka semasa ibu bapa mereka masih hidup. Ciri pertama, seperti yang saya perhatikan, tidak terlalu jelas kesannya dalam kehidupan harian warga tua. Ramai juga warga tua yang jahil dan kurang mematuhi suruhan agama, tetapi ada di antara mereka yang hidupnya senang lenang. Ciri yang kedua berkemungkinan tidak mendatangkan banyak masalah juga jika warga tua itu seorang yang patuh kepada ajaran agama. Mereka lebih redha menerima keadaan hidup mereka. Mereka tidak merasa berada dalam keadaan tidak mencukupi, ataupun jika ada merasa, mereka boleh menerimanya dengan penuh redha. Ciri yang paling utama dan yang paling ketara kesannya ke atas kesejahteraan dan keadaan keterpinggiran warga tua ialah ciri yang ketiga, iaitu pengalaman warga tua itu sendiri dengan ibu bapa mereka dahulu.

Ciri ini menguasai dan melebihi ciri lain dari segi kesan segeranya. Orang yang meninggalkan ibu bapa mereka semasa mereka muda seperti yang saya perhatikan, akan ditinggalkan oleh anak-anak apabila mereka mencapai umur tua.

Boleh dikatakan semua warga tua yang sekarang ini berhadapan dengan masalah, sama ada masalah berkaitan dengan jiran tetangga, lebih-lebih lagi 
Pesakit ini tidak banyak boleh bergantung kepada hospital kerajaan untuk menjalani rawatan kerana senarai pesakit yang menunggu giliran terlalu ramai. Pesakit terpaksa menunggu giliran sehingga berbulan-bulan baru mendapat peluang menerima rawatan percuma ini, sedangkan rawatannya tidak boleh ditangguh-tangguh. Kerana itu pesakit terpaksa mencari alternatif selain hospital. Mereka terpaksa menggunakan khidmat pusat-pusat rawatan homeodialisis swasta yang menawarkan khidmat rawatan ini. Saya menjelajah di kebanyakan tempat di negeri Kelantan, Terengganu, Kedah, Perlis, Selangor dan Kuala Lumpur untuk memerhatikan peluang perubatan ini di pusat-pusat rawatan swasta, dan adalah didapati kos perubatannya untuk sekali rawatan ialah di antara RM200 - RM250.00. Saya tidak menjumpai pusat rawatan yang menawarkan kos yang lebih rendah daripada itu, kecuali satu pusat sahaja di jalan Semenyih di Selangor, di mana kosnya hanya RM150.00 untuk sekali rawatan. Itupun fasiliti pusat ini terlalu minimum untuk keselesaan pesakit. Apakah yang boleh dibayangkan daripada kos perubatan yang sebegini? Cuba dikalikan harga tersebut dengan tiga kali rawatan yang terpaksa dilalui oleh pesakit dalam seminggu dan dikalikan lagi dengan empat minggu untuk mendapat jumlah kos perubatan sebulan. Jadi kos perubatan yang terpaksa dikeluarkan oleh warga tua desa sebulan tentulah mahal. Sedangkan pesakit, jika sudah pernah menjalani rawatan homeodialisis, mereka terpaksa melakukannya seumur hidup. Adakah warga tua desa yang tidak mempunyai jaminan kewangan mampu untuk membayar kos perubatan tersebut? Adakah anak perempuan sebagai ibu tunggal yang bermasalah seperti yang banyak terdapat dalam masyarakat pantai Timur ini dapat banyak membantu mengurangkan ibu bapa mereka yang berhadapan dengan masalah seperti ini?

\section{Cabaran Ke Atas Jaminan Kesejahteraan}

Kesejahteraan warga tua memerlukan empat komponen utama, iaitu pendapatan yang mencukupi, kesihatan dan penjagaannya, hubungan sosial yang bermakna serta sokongan sosial yang mencukupi (Cantor \& Little, 1985). Keempat-empat komponen ini berkaitan erat dengan sumber penjagaan mereka, khususnya wanita sebagai penjaga utama. Selain empat komponen ini, Wan Ibrahim Wan Ahmad (1999), berasaskan kajiannya di kawasan pedesaan Kelantan mendapati ciri-ciri latar belakang warga tua itu sendiri, seperti umur dan jantina, status perkahwinan, jumlah anak, tahap pendidikan, status pekerjaan dan pendapatannya turut mempunyai pengaruh ke atas tahap kesejahteraan warga tua. Ini menunjukkan pendapatan, sokongan dan penjagaan adalah variabel penting yang berkaitan dengan kesejahteraan warga tua. Satu lagi variabel yang penting yang tidak boleh dilupakan dalam menganalisis kesejahteraan warga tua ialah status perkahwinan mereka. Akan tetapi dengan meningkatnya wanita yang dianggap sebagai sumber penjagaan penting warga tua yang menjadi ibu tunggal boleh meninggalkan kesan negatif ke atas jaminan kesejahteraan warga tua ini.

\section{HARAPAN MASA DEPAN: MEWUJUDKAN MASYARAKAT}


ke kawasan desa, maka industri itu haruslah bersesuaian dengan keadaan sosioekonomi penduduk tersebut. Dalam konteks kawasan desa di Pantai Timur ini, industri yang sesuai adalah industri berskala kecil yang sepatutnya menggunakan bahan mentah tempatan dan mampu menyerap tenaga kerja tempatan.

Begitu juga dengan program pembangunan yang lain perlulah mengambilkira kemampuan dan kesesuaian penduduk tempatan yang ada. Tanpa mengambil kira aspek ini maka dikhuatiri program pembangunan yang dibawa akan lebih banyak mendatangkan masalah kepada penduduk tempatan, dan dengan itu hasrat kerajaan untuk membangun dan meningkatkan kualiti hidup sebahagian besar penduduk di kawasan luar bandar sukar tercapai. Keadaan seperti ini juga dikhuatiri boleh membawa kepada golongan yang kaya menjadi semakin kaya dan golongan yang miskin menjadi semakin miskin yang akhirnya memperluasan lagi jurang pendapatan di antara golongan miskin dengan golongan kaya dalam masyarakat. Akhirnya yang rugi bukanlah golongan muda, tetapi warga tua itu sendiri.

\section{KESIMPULAN}

Kesimpulannya dapat dikatakan perubahan keluarga, termasuk kewujudan ibu tunggal, boleh meninggalkan cabaran besar kepada kehidupan warga tua di kawasan desa. Sama ada warga tua sekarang ini merupakan orang yang disayangi, terpinggir daripada anak-anak ataupun tidak, ia adalah amat bergantung kepada pengalaman warga tua itu sendiri bersama dengan ibu bapa mereka yang sudah tua. Jika warga tua yang ada dalam masyarakat sekarang ini semasa mereka muda dahulu tidak menyayangi ibu bapa mereka yang sudah tua, maka mereka sekarang mempunyai kecenderungan untuk tidak akan disayangi anak-anak. Oleh yang demikian, supaya kita dikasihi semasa tua nanti, kita perlulah mengasihi warga tua, khususnya ibu bapa kita. Ibu tunggal itu sendiri juga walaupun bergelumang dengan pelbagai masalah, perlulah menganggap ibu bapa mereka sebagai sebahagian daripada tanggung jawab yang perlu mereka pikul. Jangan hanya meletakkan tanggung jawab kepada orang lain, khususnya kepada adik beradik kita yang lain. Walaupun ada adik beradik kita yang telah bertanggung jawab kepada ibu bapa kita, tugas dan tanggung jawab kita tidak terlepas. Setiap anak mempunyai tanggung jawab mereka sendirisendiri. Kehidupan sebagai seorang ibu tunggal, atau keluarga ibu tunggal adalah dianggap sebagai keluarga yang cacat. Ini kerana keluarga ini diketuai oleh hanya sorang ketua, iaitu ibu tanpa suami atau bapa. Keluarga yang cacat ini pula bergelumang dengan pelbagai masalah harian, daripada masalah batin, anak-anak sehinggalah kepada masalah perbelanjaan hidup. Akan tetapi tidaklah bermakna keluarga yang diterajui oleh ibu tunggal sentiasa bermasalah, atau tidak berpeluang menjadi sebuah keluarga yang bahagia sama seperti keluarga 
masalah dengan ahli keluarga, khususnya anak-anak, adalah warga tua yang meninggalkan ibu bapa mereka semasa mereka muda dahulu. Warga tua seperti inilah yang dijumpai terbiar, hidup merempat, tersisih dan ditinggalkan anakanak, hidup di rumah-rumah Sri Kenangan, dan lain-lain. Oleh yang demikian, jika kita ingin membentuk masyarakat yang menyayangi warga tua, ia mesti bermula daripada diri kita. Kita sendiri dahulu perlulah menyayangi warga tua, khususnya ibu bapa kita. Jika kita ingin disayangi anak-anak apabila kita sudah mencapai umur lanjut, maka apa yang perlu kita buat bukan setakat menjaga, membesar, mengasihi atau menyediakan segala keperluan anak kita. Apa yang lebih penting ialah semasa kita masih mempunyai ibu bapa, kita mesti menyayangi mereka, terutama jika mereka sudah tua. Jika tidak, kita pasti tidak akan disayangi oleh anak-anak kita. Janganlah kita sahaja yang sentiasa memikirkan apabila kita tua, kita mengharapkan anak yang akan menyayangi dan menjaga kita, sedangkan dalam masa yang sama kita melupakan ibu bapa kita di belakang. Tidakkah kita terfikir ibu bapa kita dahulupun, malah sehingga sekarang inipun jika mereka masih hidup, mereka juga mengharapkan anakanak mereka, iaitu kita sendiri, untuk menjaga dan mengasihi mereka. Tetapi kita hanya melihat ke depan, memikirkan nasib kita yang akan tua, tetapi tidak pernah berfikir tentang nasib ibu bapa kita yang sudah tua dan uzur.

Selain itu secara majoritinya ibu tunggal di Pantai Timur adalah tergolong dalam status sosial yang rendah. Mereka tidak mempunyai pendidikan yang tinggi, bekerja sebagai petani, buruh atau peniaga kecil. Pekerjaan seperti ini tidak menawarkan pendapatan yang lebih, dan sebab itu hampir keseluruhan mereka mempunyai pendapatan di bawah pendapatan garis kemiskinan. Maklumat-maklumat seperti ini adalah berguna jika perancangan sesuatu program pembangunan ingin dibawa ke kawasan desa. Banyak di antara kawasan desa di Pantai Timur mempunyai potensi yang boleh dimajukan sebagai kawasan bandar. Bagaimanapun program-program pembangunan yang dibawa jika ingin dinikmati sebahagian besar penduduk desa tempatan, mestilah bersesuaian dengan kategori penduduk yang mempunyai status sosioekonomi yang rendah.

Pembangunan industri umpamanya, walaupun industri, khususnya industri berat penting kepada ekonomi negara, tetapi industri seperti ini, lebih-lebih lagi industri berat yang berintensif modal, belum tentu dapat dinikmati oleh kategori penduduk ini. Melalui pemerhatian, pengalaman pembangunan industri berat di kawasan Kerteh-Paka umpamanya, tidak banyak yang dapat dinikmati oleh penduduk tempatan secara langsung. Disebabkan banyak peluang pekerjaan yang ada memerlukan persyaratan pendidikan dan kemahiran tertentu, maka peluang pekerjaan ini dipenuhi oleh bukan penduduk tempatan. Penduduk tempatan hanya berkeupayaan untuk mengisi jawatan-jawatan rendah yang menawarkan gaji yang kecil, sedangkan akibat daripada pembangunan industri ini, seperti harga barangan serta kos hidup yang lain turut melambung. Oleh yang demikian berasaskan pengalaman ini, maka jika industri ingin dibawa 
Social Sceinces. Edisi ke-3, disunting oleh R.H. Binstock dan Linda K. George. San Diego: Academic Press.

Chua, T. T. 1988. Some Myths and Facts about the Elderly. Jurnal Kebajikan Masyarakat 8: 1-5.

Dominian, Jack. 1981. Marriage, Faith and Love. London: Longman \& Todd Ltd.

Heisil. 1984. Ageing in the Developing World. Population Studies 11(2): 37-51.

Horwitz, Allan V. 1993. Adult Siblings As Sources of Social Support for the Seriously Mentally 111. Test of the Serial Model. Marriage and the Family, 55: 623-632.

Jabatan Perangkaan Malaysia. 1983. Laporan Am Banci Penduduk 1980, jilid 1. Kuala Lumpur: Jabatan Percetakan negara.

Jabatan Perangkaan Malaysia. 1995. Laporan am banci penduduk dan perumahan 1991, Jilid 2. Kuala Lumpur: Jabatan Percetakan Negara.

Jabatan Perangkaan Malaysia. 2006. Buletin Perangkaan Sosial. Kuala Lumpur: Jabatan Percetakan Negara.

Lembaga Penduduk dan Pembangunan Keluarga Negara (LPPKN). t.th. Profil Keluarga Malaysia. Kuala Lumpur: LPPKN

Marshall, V.M., C.J. Rosenthall\& J.Daciuk. 1987. Older Parents' Expectations for Support. Social Justice Research 1(4): 405-425.

Masitah \& Nazileh.1988. Malaysia Country Report on Socio-economic Consequences of the Aging of Population Survey, 1986. Kuala Lumpur: LPPKN.

Moore, Wilbert E. 1963. Social Change. Englewood Cliffs, New J.,; Prentice Hall.

Nor Laily Abu Bakar et al., 1980. The Malaysian Family Planning Programme: Some Facts and Figures. Kuala Lumpur: National Family Planning Board.

Palmore, J.A. , Marzuki, A. 1969. Marriage Patterns and Cummulative Fertility in West Malaysia 1950-1962. Demography, Vol. 6 (4).

Pertubuhan Bangsa-Bangsa Bersatu. 1988. World Population Prospects: Estimates and Projections as Assesed in 1982. Department of International Economics and Social Affair, New York: USA.

Pertubuhan Bangsa-Bangsa Bersatu. 1991. Sex and Age Distributions of Population. Department of International Economics and Social Affair, New York: USA.

Rohaty Mohd. Majzub \& Muhammad Rais Abdul Karim. 1999. Ibu Tunggal. Menelusuri Rintangan Hidup Dengan Keyakinan. Subang Jaya: Pelanduk Publications.

Ruggles, S \& Goeken, R. 1992. Race abd Multigenerational Structure, 19001980, dlm. J. S. Scott dan S. E. Tolnay (penyt.) The Changing American Family: Sosiological \& Demographic Perspectives. Boulder, Westview.

Stoller, E. P.1985. Parental Caregiving by Adult Children. Journal of Marriage and The Family, November: 851-858. 
sempurna yang lain. Ibu tunggal perlu mengubah sikap daripada memandang diri mereka sebagai keluarga yang bermasalah kepada melihat mereka juga sama seperti keluarga lain yang sepatutnya berpeluang menjadi keluarga ibu tunggal yang berjaya ataupun bahagia. Keluarga ibu tunggal yang berjaya ialah keluarga yang dapat menjalani kehidupan harian mereka dengan penuh keseronokan dan merasa redha dan bahagia dengan keadaan yang menimpa mereka. Keluarga ibu tunggal yang berjaya ini tidak melihat musibah (fenomena) ibu tunggal yang menimpa mereka sebagai penghalang kepada peluang untuk menikmati kegembiraan dan kemesraan di kalangan anggota keluarga, dan tidak menganggap musibah yang menimpa sebagai penghalang kepada kejayaan dan kebahagiaan. Ibu tunggal yang menjadi peneraju kepada keluarga ini sepatutnya berusaha mewujudkan satu suasana rumah tangga yang sihat, hangat dan ceria. Rumah tangga yang ceria atau bahagia tidak semestinya hanya menjadi milik keluarga yang diterajui oleh kedua-dua ibu bapa sahaja. Apabila keluarga ibu tunggal ini dapat mewujudkan suasana rumah tangga yang hangat dan ceria, maka pastilah kehadiran warga tua dalam rumah tangga mereka tidak dianggap sebagai bebanan yang terpaksa dipikul. Dengan yang demikian harapan kerajaan untuk mewujudkan masyarakat penyayang yang menyanyangi warga tua akan dapat direalisasikan.

Kajian ini menunjukkan terdapat ramai ibu tunggal dalam masyarakat Melayu sekarang. Kebanyakan mereka juga merupakan golongan penduduk yang bermasalah. Apa yang dapat warga tua harapkan jika anak-anak mereka yang dianggap sebagai sumber utama penjagaan, terdiri daripada ibu tunggal yang bermasalah? Mampukah warga tua bergantung harap untuk sokongan dan penjagaan kepada sumber yang seperti ini? Inilah implikasi penting yang wujud dan harus dihadapi oleh warga tua dalam masyarakat.

\section{RUJUKAN}

Asmah Ahmad. 1979. Pola Perkahwinan Pertama Orang-orang Melayu di Kuala Lumpur dan Petaling Jaya, Tahun 70-an: Satu Analisis Awal. Ilmu Alam: 8 (85-96).

Atchley, Robert C. 1988. Aging: Continuity and Change. Belmont, California: Wadsworth Publishing Co.

Burges et al. 1971. The Family: From Traditional to Companionship. New York: Van Nostrand Reinhold Company.

Cantor, M.H. 1979. Neighbors and Friends: An Overlooked Resources in the Informal Support System. Research on Aging, 4: 23-24.

Cantor, M \& V. Little. 1985. Aging and Social Care. Dlm. Handbook of Aging and the Social Sceinces. Edisi ke-2, disunting oleh R.H. Binstock dan E. Shanas. New York: Van Nostrand.

Chappell. N. L. 1990. Aging and Social Care. Dlm. Handbook of Aging and the 
Stoller, E. P. 1983. Exchange Patterns in the Informal Support Networks of the Elderly: The Inpact of Reciprocity on Morale. Journal of Marriage and The Family, May: 335-342.

Strange, H. 1980. The Effect of Modernization on Rural Malay Aged - A pilot Study. Jurnal Kebajikan Masyarakat 1 (2): 19 - 38.

Wan Ibrahim Wan Ahmad. 1990. Perilaku Kesuburan Penduduk Desa: Satu Kajian di Daerah Kuala Balah, Jeli, Kelantan. Tesis Sarjana Sastera. UK Malaysia.

Wan Ibrahim Wan Ahmad. 1999. Hubungan Sosial, Sokongan dan Kesejahteraan Warga Tua: Satu Kajian di Pedesaan Kelantan. Tesis Ph.D yang diserahkan kepada Fakulti Ekologi Manusia, Universiti Putra Malaysia.

Wan Ibrahim Wan Ahmad. 2000. Penjagaan Warga Tua Pada Abad ke-21: Tanggung Jawab Keluarga atau Pemerintah?, dlm.Negara, Pasaran dan Modenisasi di Malaysia, disunting oleh Abdul Rahman Haji Embong. Bangi: Universiti Kebangsaan Malaysia.

Wan Ibrahim Wan Ahmad. 2003. Ibu Tunggal di Pantai Timur: Masalah dan Strategi Adaptasi. Laporan Penyelidikan (KUSTEM Vot 54005) yang dihantar kepada Kolej Universiti Sains dan Teknologi Malaysia.

Woroby, J.L. dan R.J.Angel. 1990. Functional Capacity and Living Arrangements of Unmarried Elderly Persons. Journal of Gerontology 45: 95-101.

Yaacob Harum. 1992. Keluarga Melayu Bandar. Kuala Lumpur: DBP

Zainab Ismail. 2001. Proses Kaunseling Islam di Kalangan Pasangan Yang Bermasalah: Satu Kajian Kes di Jabatan Agama Islam Wilayah Persekutuan, Kuala Lumpur. Tesis Ph.D. Universiti Sains Malaysia, Penang.

Zawanah Muhammad. 1998. Perkhidmatan Kaunseling Perkahwinan di Jabatanjabatan Agama Islam. Tesis Sarjana. Jabatan Syariah. Fakulti Pengajian Islam, Universiti Kebangsaan Malaysia, Bangi.

Wan Ibrahim Wan Ahmad, Ph.D

Profesor Madya

Fakulti Pembangunan Sosial dan Manusia

06010 Universiti Utara Malaysia

Sintok, Kedah Darul Aman, Malaysia 